\title{
STRATEGIES FOR THE EVALUATION OF ELECTRIFICATION PROJECTS OF PUBLIC TRANSPORTATION BY BUS
}

\author{
Filipe Leonardo Cardoso Souza (https://orcid.org/0000-0003-4489-5566) ${ }^{1^{*}}$ \\ André Soares Dantas (https://orcid.org/0000-0002-2986-190X) ${ }^{2}$
}

1 Inter-American Development Bank, Asa Norte, 70800-400, Brasília, Brazil

2 Associação Nacional das Empresas de Transportes Urbanos, Setor de Autarquias Sul, 70070-944, Brasília,

Brazil

*leonardofcsouza@gmail.com

\section{Submitted: 16/08/2020. Accepted: 17/09/2020 \\ Published: 23/09/2020}

\begin{abstract}
Purpose: This paper introduces a project evaluation strategy and risk mapping for electrification of public transportation. It is also the scope for identifying the participation of institutions beyond and of the transportation ecosystem in the decision-making process of electric bus projects.
\end{abstract}

Methodology/ Approach: The methodology is based in a feasibility study to assess the applicability of electric buses according to the operational and infrastructure characteristics of the cities.

Findings: The achieved strategy presented a global vision of project elaboration, including the participation of steakholders who are not traditionally associated with planning, but are an active part of the services provision.

Research Implication: Based on the project evaluation strategy proposed is possible to reduce market or technology uncertainties, to anticipate and mitigate the identified risks to provide safer recommendations to decision makers

Originality/Value of paper: transportation planners and decision maker will now be able to make decisions based on a thorough assessment of the compatibility of electric buses with the respective cities

KEYWORD: electro mobility; public transportation; electric buses.

\section{ESTRATÉGIAS PARA AVALIAÇÃO DE PROJETOS DE ELETRIFICAÇÃO DO TRANSPORTE PÚBLICO POR ÔNIBUS}

\section{RESUMO}

Objetivo: Este artigo apresenta uma estratégia de avaliação de projeto e mapeamento de risco para eletrificação de transporte público. É também o escopo para identificar a participação de instituições de fora e do ecossistema de transportes no processo de tomada de decisão de projetos de ônibus elétricos.

Metodologia / Abordagem: A metodologia é baseada em um estudo de viabilidade para avaliar a aplicabilidade dos ônibus elétricos de acordo com as características operacionais e de infraestrutura das cidades.

Resultados: A estratégia apresentou uma visão global de elaboração de projetos, incluindo a participação de steakholders que tradicionalmente não estão associados ao planejamento, mas são parte ativa da prestação de serviços.

Limitações da pesquisa: Com base na estratégia de avaliação proposta, é possível reduzir as incertezas do mercado ou da tecnologia, antecipar e mitigar os riscos identificados para fornecer recomendações mais seguras aos tomadores de decisão.

Originalidade / valor do artigo: planejadores de transporte e tomadores de decisão agora poderão tomar decisões com base em uma avaliação completa da compatibilidade dos ônibus elétricos com as respectivas cidades

PALAVRAS-CHAVE: eletromobilidade; transporte público; ônibus elétricos. 


\section{INTRODUCTION}

The electro mobility in public transportation by bus necessarily involves the elaboration of detailed projects on the viability of electric buses. This is perceived when considering the immaturity and charging of the lithium-ion battery technology or the high business risk associated with the large volumes of investments to implement the technology. According to Zeeus (2019), it is necessary that project details include financial, economic, environmental and social aspects, plus the adequacy to the current transportation systems of cities and metropolitan regions. Thus, the choice of an adequate and reliable strategy for the evaluation of electrification projects becomes the first step for the application of the electric propulsion system in urban bus systems.

A basic feasibility study for electrification projects could provide to decision makers a security regarding investment and the support necessary for the application and development of electro mobility in cities. Through this strategy, it is possible, for example, to build a more solid electrification process, which will allow reducing technology uncertainties, as well as potentializing the possible benefits of using electric vehicles. It is worth mentioning that electric buses have barriers inherent to all emerging technologies, such as the high cost of implementation and risks associated with the business (Greenpeace, 2016, D'agosto, Gonçalves \& Almeida, 2017; Slowik, et al., 2018, Lebeau, Lebeau, Macharis \& Mierlo, 2013; Vaz, 2015). Given the importance of public transport for cities, it is relevant that any modification, especially structural, such as the replacement of the propulsion system, should come up in studies that allow us to glimpse not only the long-term economic and financial viability, but also the technical viability, environmental and social aspects of new transport projects.

Without well-defined and clear evaluation strategies as to the scope, breadth or detail required, the design and feasibility of electrification projects may be compromised (Zeeus, 2019; Tcrp, 2018, Slowik et al., 2018, WRI, 2017). In addition, without a pre-assessment step, important risks that need to be considered and mitigated can be omitted from the electrification process. In these cases, these strategies will then support decisions disconnected from the operational or market reality of each region. Thus, the high investment made, which today is estimated around $\mathrm{R} \$ 3$ million/vehicle over 20 years (Byd, 2019), may not bring the expected financial returns, resulting in losses for transport systems (Slowik et al., 2018). These negative effects can be even greater when assessing the malfunction of cities through wrong or inefficient operating decisions in the transport system (e.g. the allocation of electric vehicles on routes that were not designed to electric propulsion in the past).

All stakeholders of the public transport ecosystem (government, operators, customers, industry and civil society) are a part of the process to conduct strategies for design and evaluation of transport systems. They are operators, customers, suppliers, solution providers, civil society, among others, who are impacted and directly influenced by the electrification of public transportation. Each actor in the ecosystem is responsible for the successful implementation of electric buses in transportation systems. The replacement of propulsion technology requires complex and multidisciplinary projects that, in the first instance, need to respond to decision makers on the feasibility and effectiveness of electro mobility in transportation systems. However, in a second moment, it lacks the participation of all actors involved in the offer and availability of services associated with electric buses. This will only be possible with the participation and sharing of risks with all parts of the system.

The main objective of this paper is to establish a strategy for the evaluation of electrification projects for public transport by bus. This strategy is supported by the economic, environmental, social and operational sustainability of electro mobility. It is expected that decision makers elaborate this feasibility study based not only on projects that aim to return the investment, but mainly, to seek the effectiveness and quality of services offered in public transport. It is also the scope of this paper to indicate the preliminary actions necessary to subsidize the elaboration of 
electrification projects and to map the contribution of different actors of the ecosystem to the success of electric buses in transport systems.

In addition to this introductory section, this document is structured in 4 other sections. In the bibliographic review, it is presented a succinct view on the use and evaluation of electric buses worldwide. The following section presents the steps that make up the work's methodology. Finally, the results presented for the construction of the risk matrix and the final considerations are presented.

\section{LITERATURE REVIEW}

Electric buses are present in every discussion about alternatives to traditional internal combustion vehicles. The operation with these vehicles potentially brings cities benefits in different aspects. From an environmental point of view, electric vehicles eliminate the emission of local pollutants, such as Particulate Material, in addition to $\mathrm{NOx}$ and $\mathrm{CO}_{2}$ (Cooney, 2011; Falco, 2017; Ercan, Zhao, Tatari \& Pazour, 2015; Elgowainy, Han, Poch, Wang, Vyas, Mahalik \& Rousseau, 2010; Millo, Rolando, Fuso \& Mallamo, 2014; Argone, 2010; Slowik et al., 2019; Zeeus, 2018; Noel \& Mccormack, 2014; Eudy, 2016). These vehicles can also contribute to the comfort in customer and workforce of public transportation, since they emit less noise during operation (Greenpeace, 2016; Useche, Gómez \& Cendales, 2017). Electric buses are also reducing important cost items associated with diesel technology, such as fuel consumption (around 40\%) and vehicle maintenance (eliminating costs for diesel-associated parts) (Slowik et al., 2018; D'agosto et al., 2017). This will directly contribute to the overall reduction of operating costs for transport systems. Many of these results have already been confirmed in practice by several cities around the world. A number of cities in recent years have started, even though through tests, the operation with electric vehicles, which are mostly by battery (Zeeus, 2018). In addition to theoretical studies, practical studies based on field tests and experiences stand out (Wilson, 2014; Grutter, 2015; Tcrp, 2018). These studies usually analyse the performance of a bus, a bus line or, possibly, an already established fleet of buses (Wilson, 2014; Grutter, 2015).

Several countries are adopting, initially on a small scale, battery electric buses to compose part of the urban bus fleets (Tcrp, 2018; Zeeus, 2016, Labmob, 2020). This initiative is the pilot project for the electrification of public transport. At this stage, it is possible to have a closer look at the operational and financial performance of vehicles in the local context. Pilot projects are a strategy to minimize the risks and the impact of the lack of technology maturity (Zeeus, 2016; Zeeus, 2018; Basso, 2011; Ding, 2015). In Europe, in 2016, 21 countries had created pilot projects for battery-powered electric buses, including Germany, the United Kingdom, Switzerland and Poland (Zeeus, 2016). In Latin America, there are 1,229 battery powered electric buses in operation, which include pilot projects or operation in small fleets (Labmob, 2020). Several studies and reports already share the first results from the operation of these pilot projects. However, there are still key questions that need to be answered, and technology parameters that can vary significantly from the results obtained. In the evaluated studies, the performance indicators vary almost $100 \%$, from 0.8 to 1.5 kWh/km (Grutter, 2015; Mattes, 2018; Xylia, Leduc, Patrizio, Kraxner \& Silveira, 2017; UITP, 2018; Eudy, 2016; Bi et al, 2016; Wilson, 2014). Cost items vary by more than $100 \%$, going from $\mathrm{R} \$ 750,000$ to R \$ 1,700.00 per vehicle (Chaves, 2019; D'agosto et al., 2017, BYD, 2019, Eletra, 2019). Even on the useful life of lithium-ion batteries, the results can vary from 2.2 to 15 years (Ercan et al., 2015; Tong et al., 2017; Cavaglia, 2014; Tong, Hendricksonb, Biehlerd, Jaramillo \& Sekib, 2015; Flyer, 2016; Zhou, Wu, Zhou, Wang, Ke, Zhang \& Hao., 2016; Laizānsa, Graursc, Rubenisa \& Utehinc, 2016; Noel \& Mccormack, 2014).

Technological or commercial uncertainties about electro mobility contribute to the restraining of the technology development in the context of public transport (Tcrp, 2018). Certainly, mapping the risks associated with electrification projects would allow cities to anticipate mitigating or to manage these uncertainties. The expansion of electric buses, mainly on a large scale, is still a challenge for transport systems ( $\mathrm{Li}$, Gorguinpour, Sclar \& Castellanos, 2019). In addition to 
technical and operational challenges, there are trade, political or often institutional barriers. Few transport systems can count on electro mobility incentive policies, as in the case of Paris (France) and Copenhagen (Denmark) (Slowik et al., 2018). Tax incentives are offered for the development of technology, mainly for infrastructure (Tesar et al., 2020). Some American cities have funded about $80 \%$ of pilot projects with specific support funds for sustainable development (Tcrp, 2018). It was indicated that without access to "green" funds, experiments with electric buses would not be possible. There are several transport policies for the expansion of electric buses, such as quotas for clean vehicles, direct subsidies from consumers or planning policies. These policies would not only assist in the development of technology, but also would directly contribute to the competitiveness of electro mobility and reduce the business risks associated with electric propulsion.

\section{MATERIAL AND METHODS}

The proposed methodology for the feasibility study of electrification of public transportation will include the elaboration of a risk matrix for the implementation of electric propulsion projects. Operational, economic, social and environmental aspects will be part of the risk matrix in the context of each city. In the first stage of the feasibility study, advances in technology around the world will be mapped. In the second stage, the characteristics of the region that can be analysed or studied for the implementation of electro mobility will be indicated. This process will culminate in a structured methodology for assessing the compatibility of the technology, whose main objective is to map the risks for the city and for the transport system by implementing the electric propulsion technology. The detailed literature review is required, one which can allow for the establishment of precise instruction for the implantation of electric vehicles in cities. The steps mentioned above are detailed below.

Step 1: Technology frame, which will "map" the development status of electric buses worldwide. In this stage, fundamental parameters and indicators for modelling local public transport will also be established. In recent years, several cities have started to operate electric vehicles. Therefore, new indicators and results will be generated each year. Thus, it will be essential to monitor the continuous evolution of technology in order to better define the risks that will be assumed in the project preparation phase. Art study methods and interviews with local electric bus operators were adopted at this stage. (Tcrp, 2018, Li et al., 2019, Slowik et al., 2018; Wilson, 2014; Grutter, 2015).

Step 2: Requirements of the city features, which will indicate the "status" of some sectors of the city, linked to the electrification process. In this stage, characteristics related to the transport system, the infrastructure of cities, the commercial offer of the industry and technology suppliers in the analyzed regions will be considered. This picture is the stage that will point out what adjustments will be necessary to receive the technology in the local transport systems. These adjustments can be in the political, financial, commercial, technological or other areas. In this stage, the best practices indicated in practical cases of electrification of public transport around the world were used (Zeeus, 2018, Zeeus, 2017, Li et al., 2019, Tcrp, 2018, Slowik et al., 2018, Falco, 2017; Siqueira, Pinheiro \& Tavares, 2019).

The risk matrix that will be used in the evaluation process for electrification projects will allow decision makers to understand which and how the technology features of the can be applied in the context of each region. It will be possible, for example, to identify and anticipate risks for the cities using electric buses. Therefore, a study will allow to strategically evaluate the requirements for technology compatibility, as well as in mapping key partnerships for electrification.

\section{RESULTS}

The compatibility study will allow cities to deepen their practical knowledge about electric buses. This strategy is essential to reduce the risk of implementing the technology and for planning electrification in the context of each region. Transport systems with similar characteristics should be 
sought in terms of business model, fleet composition, governance structure, geographical characteristics or even political characteristics. In this process, one can also learn about good practices and successful experiences, such as learning about experiences that did not generate good results. All of this information will be fundamental in the elaboration of electrification projects for public transportation in cities.

\subsection{Frame of public transportation by bus's electrification}

Several studies and reports contribute to the knowledge about the experience of electro mobility in public transport. In the theoretical field, studies such as Greenpeace, 2016; Argone, 2010; Slowik et al., 2018; Ercan et al., 2015; Zeeus, 2019; Noel \& Mccormack, 2014; Eudy, 2016; among others, defend the use of the electric bus as an extremely advantageous alternative. These advantages are mainly environmental and financial, compared to the traditional diesel bus. Commonly mentioned benefits are the elimination of the emission of local pollutants or the saving in operating costs by reducing fuel consumption (around 25 to 40\%) and vehicle maintenance (elimination of costs with parts associated with diesel). Some of these studies are more specific and delve into the details of some characteristics of the electric bus. The California Air Resources Board (2016) and Zhou et al. (2016) study on battery analysis are cited, along with the study by Zeeus (2016), Lajunen \& Lipman (2016), Lindgren (2015) and Xylia (2017) for the structure of chargers and even Falco (2011), Tong et al. (2017), CARB (2015), Zhou (2016) for environmental impacts. In addition, studies that are more general address several parameters of technology, such as $\mathrm{Bi}$, Kleine \& Keoleian (2016), Aber (2016) and Lajunen (2016).

In addition to theoretical studies, practical studies based on tests and field experiences stand out (Wilson, 2014; Grutter, 2015; TCRP, 2018). These studies usually analyze the performance of a bus, a bus line (Wilson, 2014) or, possibly, an already established fleet of buses (Grutter, 2015). Through these studies, some premises found in theoretical studies could be followed up in practice. In addition, essentially, the operation reports, added by the local experience of operating the electric buses. In these studies, only aspects related to the operation of these vehicles are usually evaluated, being restricted to performance indicators, which are fundamental in modeling the elaboration of projects.

Based on the before mentioned experiences (both theoretical and practical), a frame of the electric propulsion technology in public transportation was made. This frame includes the convergence of several premises and perspectives for electrification projects that need to be considered in the compatibility assessment process for each city. These premises, in the first instance, will serve to understand the maturity of the technology. Secondly, together with the evaluation of the city characteristics, they will serve to define the electrification strategies of the region.

- Electro mobility generates environmental benefits by reducing or eliminating pollutant emissions. This fundamental premise needs to be verified, especially in cases where the energy source that feeds the system results in emissions higher than those already practiced by the diesel's chain. There are also emissions from the production and disposal of batteries, which must be accounted for and compose the environmental inventory of the system (from the cradle to the grave);

- The financial benefit of electrification projects, together with the environmental benefit, are the viability pillars of electric buses. Reductions in some cost items (fuel consumption and maintenance) should be checked. On the other hand, there are uncertainties regarding the technical capacity of the workforce and availability of the new technology's consumption chain, which would lead to the dependence on specialized professionals and warehouses with greater stocks, for example. Therefore, the premise of financial return must be detailed in the preparation of the projects; 
- The technological advancement of lithium ion batteries has made it possible to apply electric buses to certain lines, but not all. Public transport systems comprise several line topologies. For each context, the technology will be adapted or not (battery powered electric bus). Longer lines, therefore, will require batteries with greater capacity or charging per opportunity throughout the operation;

- The first tests pointed to operational viability of battery powered electric buses, but for small fleets. There is evidence of cost savings for the analysed projects, but there are countless variables that need to be considered according to the specificity of each location: relief, type of line, number of refills, etc. It is based on the premise that the technology works, however it is necessary to know the efficiency in the operation of the system in each location as a fundamental point in the feasibility study of electrification projects. This indicator is considered essential for the success of the projects;

- The implementation of the electric bus fleet necessarily involves specific funds for financing and encouraging technology. The transport systems that started operating with electric buses had about $80 \%$ of the initial costs financed by specific funds for the development of technology in public transport; and

- For the operation and maintenance of vehicles, investment in the training of labour is necessary. The technology transition implied new demands for knowledge and workers, both for vehicle operation and maintenance.

This is the situation of electro mobility in public transportation today (2020), but as already mentioned, continuous monitoring of this picture is part of the compatibility assessment process. This will allow the elaboration of electrification projects to be based on recent data, which will contribute to modelling and strategies closer to reality. This portrait will serve as a reference in decision-making. Thus, electrification strategies will consider increasingly consolidated premises, which will certainly be beneficial for the evaluation and development of technology in the context of cities.

\subsection{Requirements of the city features}

Requirement studies for the implementation of electric buses go beyond the analysis of traditional transport ecosystems. In addition to the institutions that are already part of the public transportation ecosystem, partnerships with other segments will be necessary, such as the electricity sector (Slowik et al., 2018). New suppliers of technology, industry, service and fuel will be involved in the electrification process. Therefore, the portrayal study of the cities features will not only assess the specificities of local public transport systems, but all those requirements considered fundamental for the development of projects. The strategies that will guide the electrification process must include requirements that incorporate, for example, the evaluation of the capacity of the electricity supply network, the availability of suppliers for parts and services, among others.

The frame of the cities features will be constructed to assess the technology adaptability requirements for each region. That is, if in the technology picture it was identified that for the application of vehicles, it is necessary to discuss and promote policies to encourage the development of electro mobility, this step will seek to assess in the local context, in which policies can be created (if they do not already exist) to meet this demand. Another example is the verification of the evolution of parameters considered critical in other systems, as in the case of battery autonomy or in the necessity to adjust the business model. Thus, in the elaboration of the portrait of the city features, studies will be carried out allowing to evaluate if there are bus lines compatible with the autonomy of batteries / charging strategies available in the market, or if the current business model could meet the costs for electrification.

From the technology review, it was identified what are the necessary actions to solve the questions about the adaptability of electric propulsion. These studies will, as a priority, check if the technology premises can be realized with the specificities and conditions offered by each city. In 
addition, in each action, the actors of the transportation ecosystem who are essential for the execution of this stage will also be identified, allowing a complete analysis of the electrification process.

- Evaluation of bus lines that are eligible for the technology available on the market, considering operational characteristics, possible loading, maintenance strategies, etc. At this point, it is necessary to establish the scope of the project in terms of the size of the fleet that can be electrified. For this, the participation of vehicle operators and automakers is essencial to ensure that the technology is compatible with the conditions of the lines and the city;

- Environmental assessment of public transport, considering mainly the life cycle of vehicles and the generation and supply of propulsion energy. This requirement is fundamental for the environmental justification of the technology in the local reality. It should include, mainly, vehicle assemblers, operators, electric energy distributors and the public power. Several studies (Cooney, 2011; Falco, 2017; Ercan et al., 2015; Elgowainy et al., 2010; Millo et al., 2014) establish specific methodologies for public transportation by bus;

- Market study of the electrification project, which includes budgets for vehicles, batteries, guarantees, financing, etc. It is necessary that these budgets are made according to the cost calculation methodologies used in practice. This will allow not only the assessment from the point of view of financial investment, but also in terms of the allocation of resources necessary for operation and the impact on the technical fees. This strategy allows the creation of indicators that allow evaluating the additional cost for the adoption of the technology. This stage includes operators and public authorities. In addition, input suppliers in the sector can be included;

- Mapping of available business models and necessary contractual adjustments. This action must also contemplate the reduction of risks for transport systems due to the high allocation of resources in the new technology. These models must include both investment in infrastructure and electric vehicles, as well as the entire system of internal combustion vehicles. This stage includes operators, public authorities and possible agents of the new business model;

- Survey of vehicle acquisition mechanisms and charging infrastructure, which includes analysis of financing strategies and the possible creation of specific funds to encourage technology. This survey can be carried out based on the guidelines established for the business model. Thus, it is necessary to define whether the system's debt capacity, for example, is compatible with the resources needed for electrification. In addition, it is necessary to establish how and under what conditions the financing achieves better economic results in the projects. This stage has the direct participation of operators, public authorities and financing agents;

- Study on the availability of services, components and local maintenance of the new propulsion technology, which includes everything from the acquisition of vehicles to the exchange of components and training of the employees. Establishing these relationships is essential for the continuity of service operations. It is necessary, together with suppliers in the sector, to establish the products chain and services associated with electric vehicles. For this, the participation of operators, vehicle manufacturers and providers of electro mobility solutions and services is required; and

- Evaluation of the electricity distribution and storage infrastructure, mainly considering the operational characteristics of the infrastructure of the garages and supply of the electric network. Therefore, a complete assessment of the supply capacity, 
infrastructure conditions at peak times, among others, for different electrification scenarios should be carried out with the electricity distributors.

The results from the aforementioned actions will certainly validate or allow checking the premises found in other studies and projects for the reality of the local operation. This will assist and technically subsidize decision-making and the elaboration of electrification projects. To carry out each of these actions, it will be necessary for each city to collect process and analyse local data. This is what will characterize the operating or market conditions and make the models for evaluating projects according to the specificities of each city.

\subsection{Risk matrix}

In cases where the city does not offer any of the requirements for the operation of electric buses, it can be understood that there is a risk for electrifying the public transportation. However, these risks can be mapped, mitigated or managed. Risks may be associated with the different stages of the project and with different impacts for the city (TCRP, 2018). Thus, there are priority risks that will lead to more efforts in management and attention in the preparation of projects. These are mainly the risks associated with the operational and financial viability of the projects (Lebeau et al., 2013; Vaz, 2015). The identification of risks in the electrification process does not necessarily imply that the project is not viable, but it does bring a warning signal that should be considered in the decision-making process. The mapping of these risks is the result of the analysis and relationship between the portraits of technology and the characteristics of cities.

Based on these analyses, a structured assessment (risk matrix) was developed with the objective of subsidizing the risk mapping and management process for each city. Risks were mapped in all stages of the project, which includes everything from the pre-planning stage to the day-to-day operation. In the pre-planning stage, risks associated with the necessary requirements for decision-making and on the maturity of electro mobility were identified. In the strategic planning stage, risks associated with financing requirements, regulation and basic planning of electric buses were mapped. These risks were mapped both analyse the technology and the city's characteristics. In the stage of specifying the electric bus, commercial and technical risks were indicated for the elaboration of the projects. These are risks associated with the technical specification requirements of the vehicles, fleet and infrastructure acquisition and long-term development of the projects. Finally, in the operation stage, vehicle maintenance and operation risks were mapped. These are mainly from the mapping of city features and the practical studies raised in the compatibility study. Figure 1 presents an illustration of the first level of the risk matrix.

Still in Figure 1, there are actions for detailing the risks in each of the phases of the electrification projects. These actions are studies, reports, research or surveys that seek to better understand the identified risks. These actions can be restricted to those that assess only the projects' sustainability bias (economic, social and environmental feasibility analyses). It is possible to add actions that determine greater depth in risk studies and that will incorporate aspects of operation, commerce, technology, among others, in the evaluation process. Also in the risk matrix, the results of the studies in the previous process will be evaluated. The risks will be confirmed (or discarded) and quantified, which will allow the development of more assertive and efficient risk management plans. In addition to allowing a detailed assessment of the risks of electrification, it will potentially be possible to identify who are responsible for the risks. This may also assist in the drafting of contracts or key partnerships for the development of electro mobility in local public transport. 


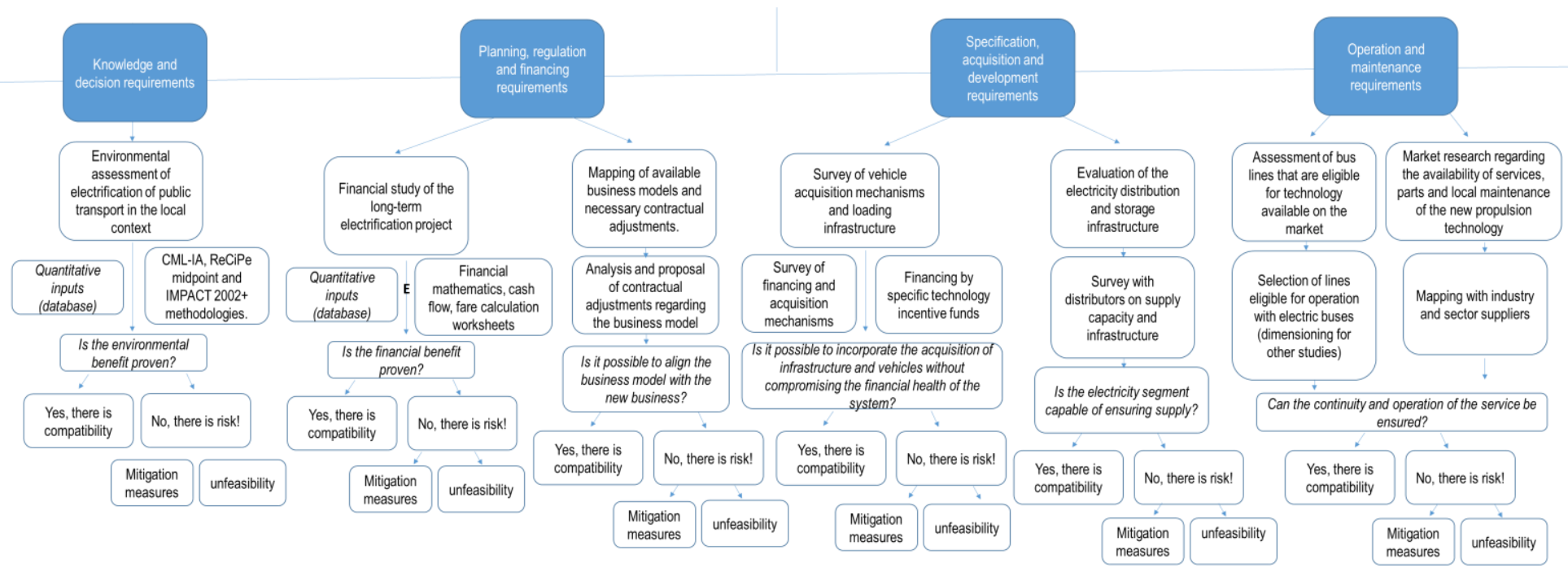

Figure 1 - Risk matrix for evaluating electrification projects for public transport by bus

Through the risk matrix, electrification projects can be recommended for approval even if they are not fully compatible in the feasibility analysis. However, in these cases, it is necessary to establish both in the feasibility report and in the preparation of the projects, the recommendations and risk mitigation mechanisms for the electric propulsion technology identified. That is, the initial incompatibility of the technology, either with the transport system or with the city, can be overcome. In some cases, the risks will not even influence the local reality. In other cases, these risks may compromise the viability of the projects. The effects will vary from city to city. If it is impossible to mitigate the risks identified in the compatibility study, the project must be rejected and the decision makers recommended the study of alternative measures to the internal combustion system. The presence of risks that cannot be circumvented or that reinforce the incompatibility of electro mobility can harm transport systems and lead to the gradual degradation of systems over the years.

\section{CONCLUSION}

The strategy of evaluating electrification projects for public transport by bus proposed in this paper sought in experiences and reports around the world the best practices and methodologies applied in the different areas of operation of electric vehicle technology. Thus, it was possible to establish a strategy that allows evaluating the compatibility of electric buses according to the specificities of each city. The steps that compose this strategy include the different phases for project design: basic project, financial project, executive project and operational project. This added to the strategy presented in this work a global and detailed view on the applicability of the technology, which provides better understanding and security to the decision makers regarding the impacts and requirements necessary to make the electro mobility of public transport viable.

The projects conceived by the strategy presented here, probably, will have lesser risks associated with electric propulsion technology. This is possible since the global analysis carried out allows the detailing and anticipation of risks and, consequently, the proposition of mitigation measures so that the effects are managed and does not result in losses to the project. Then, uncertainties about the success of the implemented projects are reduced. In addition, the management of these risks is added to the experience and participation of other actors in the ecosystem who did not previously participate in the decision-making process. However, in the proposed methodology, they will be directly associated with the services offered and, therefore, considered of extreme relevance in the project discussion phase and feasibility study.

The engagement and availability of the main players in the transport ecosystem is also part of the strategy for electrifying public transportation. It is necessary to disscuss and listen to the different actors who live in the transport ecosystem. The changes resulting from electrification are 
not restricted to the operation (operator-public authority), but also affect the entire service chain that formerly operated, mostly, with internal combustion vehicles. It is necessary to bring them, listen to them and contribute to a more robust electrification strategy, which incorporates not only financial or environmental viability, but also the entire service chain.

Some proposals for the future development of electric bus projects and electrification of public transport were identified across this paper. They are mainly of public policy, planning and understanding of the characteristics of technology in order to adapt reality to the specificities of electric propulsion, as in the case of infrastructure and financing, for example. Below are some referrals from this work:

- Detailed studies of the electrical technology life cycle are necessary, considering the characteristics of the region, mainly regarding the necessary inputs and electricity generation. This requirement may compromise the justification for replacing diesel with electric propulsion technology (the battery);

- Detailed long-term financial assessment of the necessary investments and the impact on the current costing model for local public transportation (survey of financial requirements for viability);

- Study of contract models that allow the incorporation of electric buses in transport systems, including establishing critical parameters to be ensured for business viability;

- Include in the electric bus projects the financing model associated with the technology, which must include not only the initial capital cost, but also the costs of the technical fare. Thus, the projects will minimize the risks to the user's accessibility to the service provided;

- $\quad$ There is a need for incentive policies for industry and suppliers of electric propulsion technology. This will reduce dependence on local systems from foreign suppliers and guarantee a market that will favour project maintenance strategies;

- The reuse or disposal of batteries should be incorporated into the electric bus project as a fundamental point in the environmental planning of the technology;

- Creation of a repository of information about the experiences and operation of electric vehicles in each region. This will assist in a better understanding of technology in the local scenario and will assist in more assertive project decisions, thus reducing business risk.

\section{REFERENCES}

Aber, J. (2016). Electric Bus Analysis for New York City Transit. New York City Transit, Columbia University, Nova York, EUA.

Basso, C. (2011). O Impacto dos Veículos Elétricos Plug-in no Sistema Elétrico de Potência. Trabalho de Conclusão de Curso, Universidade Federal do Pampa

Bi, Z.; Kleine, R.; Keoleian, G. A. (2016). Integrated Life Cycle Assessment and Life Cycle Cost Model for Comparing Plug-in versus Wireless Charging for an Electric Bus System. Jornal of Industrial Ecology, 21, 344-355. https://doi.org/10.1111/jiec.12419

Byd (2019). Entrevista com representante da BYD no Seminário Nacional NTU 2019. Brasília, DF

Carb (2016). Battery Cost for Heavy-Duty Electric Vehicles. California Air Resources Board, California, EUA

Carb, California Air Resources Board. (2015). Low carbon fuel standard. Final Regulation Order, Title 17, California Code of Regulations. Available in <https://www.arbca.gov/regact/2015/lcfs2015/lcfsfinalregorder.pdf>. Accessed $15 / 08 / 2020$

Cavaglia, B. (2014). Interview Local Government Turin (Citta’ Di Torino)

Chaves, L. R. (2019). Elétricos no horizonte. Edição 283. Available in: < https://revistapesquisa.fapesp.br/2019/09/06/eletricos-no-horizonte/>. Accessed: 09/09/2019 
Cooney, G. A. (2011). Life cycle assessment of diesel and electric public transportation buses. Masters Dissertation, University of Pittsburgh, Pennsylvania, EUA

D’agosto, M. A.; Gonçalves, D. N. S.; Almeida, I. R. P. L. (2017). Ônibus elétricos a bateria (plug-in): Uma primeira avaliação da viabilidade econômica e do impacto na tarifa para o uso nas cidades brasileiras. Transportation Engineering - PET/COPPE, Universidade Federal do Rio de Janeiro, Rio de Janeiro, Brasil

Ding (2015). Value of the energy storage system in an electric bus fast charging station. Department of Electrical Engineering, Tsinghua University, China

Eletra, 2019. Entrevista com representante da Eletra no Seminário Nacional NTU 2019. Brasília, Brazil

Elgowainy, A; HAN, J.; POCH, L; WANG, M.; VYAS, A; MAHALIK, M.; ROUSSEAU, A. (2010). Well-to-wheels analysis of energy use and greenhouse gas emissions of plug-in hybrid electric vehicles. Argonne National Laboratory, Chicago University, EUA

Ercan, T.; Zhao, Y.; Tatari, O, Pazour, J. A. (2015). Optimization of transit bus fleet's life cycle assessment impacts with alternative fuel options. Energy, 93, 323-334. https://doi.org/10.1016/j.energy.2015.09.018.

Eudy, L. (2016). Foothill Transit Battery Electric Bus Demonstration Results. National Renewable Energy Laboratory, Golden Coast, EUA

Falco, D. G. (2017). Avaliação do desempenho ambiental do transporte coletivo urbano no estado de São Paulo: uma abordagem de ciclo de vida do ônibus a diesel e elétrico à bateria. Faculdade de Engenharia Mecânica da Universidade Estadual de Campinas, Campinas, SP

Flyer (2016). New Flyer Xcelsior ${ }^{\circledR}$ XE40 Battery-Electric Bus Port Authority of Allegheny County Demonstration Report. New Flyer, Pittsburgh, EUA

Greenpeace (2016). Dossiê Ônibus Limpo - Benefícios de uma transição para combustíveis renováveis na frota de São Paulo. São Paulo, Brazil

Grutter, J. (2016). Real World Performance of Hybrid and Electric Buses. Grutter Consulting, Reinach, Schweiz

Labmob, 2020. Plataforma E-bus Radar. Available in < https://www.ebusradar.org/>. Accessed 17/07/2020

Laizānsa, A.; Graursc, I.; Rubenisa, A.; Utehinc, G. (2016). Economic Viability of Electric Public Busses: Regional Perspective. Procedia Engineering, 134, 316-321. https://doi.org/10.1016/j.proeng.2016.01.013

Lajunen, A.; Lipman, T. (2016). Lifecycle cost assessment and carbon dioxide emissions of diesel, natural gas, hybrid electric, fuel cell hybrid and electric transit buses. Elsevier Ltda.

Lebeau, K.; Lebeau, P.; Macharis, C.; Mierlo, J. V. (2013). How expensive are electric vehicles? A total cost of ownership analysis. World Electric Vehicle Journal, 6, 999-1007. https://doi.org/10.3390/wevj6040996.

Li, X.; Gorguinpour, C.; Sclar, R.; Castellanos, S. (2019). How to enable electric bus adoption in cities worldwide: a Guiding Report for City Transit Agencies and Bus Operating Entities. World Resources International - WRI. Available in < https://www.wri.org/publication/how-enable-electric-bus-adoption-cities-worldwide>. Accessed 15/08/2020

Lindgren, L. (2015). Full electrification of Lund city bus traffic - A simulation study. Department of Industrial Electrical Engineering and Automation, Lund Institute of Technology

Mattes, P. (2018). Performance of an Electric Bus, Powered by Solar Energy. VII Congresso Brasileiro de Energia Solar

Millo, F.; Rolando, L.; Fuso, R.; Mallamo, F. (2014). Real CO2 emissions benefits and end user's operating costs of a plug-in Hybrid Electric Vehicle. Applied Energy, 114, 563-571. https://doi.org/10.1016/j.apenergy.2013.09.014

Noel, L.; Mccormack, R. A cost benefit analysis of a V2G-capable electric school bus compared to a traditional diesel school bus. Applied Energy, 126, 246-255. https://doi.org/10.1016/j.apenergy.2014.04.009

Siqueira, F. H.; Pinheiro, B. C.; Tavares, V. B. (2019). Panorama sobre o monitoramento do desempenho de ônibus elétricos. $33^{\circ}$ Seminário ANPET. Balneário Camboriú, Brazil.

Slowik, P; Araújo, C.; Dallmann, T.; Façanha, C. (2018). Avaliação Internacional de Políticas Públicas para Eletromobilidade em Frotas Urbanas. Ministério da Indústria, Comércio Exterior e Serviços, Brasília, DF

Tcrp (2018). Battery Electric Buses State of the Practice - A Synthesis of Transit Practice. Synthesis 130. Transit Cooperative Research Program, Washington - DC, EUA

Tesar, M., Berthold, K., Gruhler, J. P., \& Gratzfeld, P. (2020). Design Methodology for the Electrification of Urban Bus Lines with Battery Electric Buses. Transportation Research Procedia, 48, 2038-2055. https://doi.org/10.1016/j.trpro.2020.08.264 
Tong, F.; Hendricksonb, C.; Biehlerd, A.; Jaramillob, P. (2017). Life cycle ownership cost and environmental externality of alternative fuel options for transit buses. Transportation Research Part D: Transport and Environment, 57 , 287-302. https://doi.org/10.1016/j.trd.2017.12.008

Tong, F.; Hendricksonb, C.; D, Biehlerd, A.; Jaramillo, P.; Sekib, S. (2017). Life cycle ownership cost and environmental externality of alternative fuel options for transit buses. Transportation Research Part D, 57, $287-302$. https://doi.org/10.1016/j.trd.2017.09.023

Uitp (2018), Infraestrutura Básica para Ônibus Elétrico a Bateria. Relatório de recomendações, Transport \& Urban Life, Latin America

Useche, S., Gómez, V., \& Cendales, B. (2017). Stress-related psychosocial factors at work, fatigue, and risky driving behavior in Bus Rapid Transport (BRT) drivers. Accident Analysis \& Prevention, 104, $106-114$. https://doi.org/10.1016/j.aap.2017.04.023.

Vaz, L. F. H. (2015). Veículos híbridos e elétricos: sugestões de políticas para o segmento. BNDES Setorial, p. 295-344 Wilson, G. (2014). Resultados do Teste com o Ônibus Elétrico na Cidade do Rio de Janeiro. FETRANSPOR, Rio de Janeiro

WRI (2017). Modelo de Negócio para adoção de ônibus elétricos. Seminário E-Mob GIZ. World Resources International, Brasília, Brasil

Xylia, M.; Leduc, S.; Patrizio, P.; Kraxner, F.; Silveira, S. (2017). Locating charging infrastructure for electric buses in Stockholm. Transportation Research Part C: Emerging Technologies, 78, 183-200. https://doi.org/10.1016/j.trc.2017.03.005.

Zeeus (2016). Grid impacts of electric bus system based on depot charging. Zero Emission Urban Bus System, Version 1.9

Zeeus (2017). ZeEUS eBus Report \#2. Available in < https://zeeus.eu/uploads/publications/documents/zeeusreport2017-2018-final.pdf>. Accessed 15/08/2020

Zeeus (2018). Tender Structure for Urban Electric Bus Procurement. Zero Emission Urban Bus System, 1

Zeeus (2019). Urban E-bus Systems Deployment Plan and Recommendations. Zero Emission Urban Bus System;

Zhou, B.; Wu, Y.; Zhou, B.; Wang. R; Ke, W; Zhang, S.; Hao, J. (2016). Real-world performance of battery electric buses and their life cycle benefits with respect to energy consumption and carbon dioxide emissions. Energy, 96, 603613. https://doi.org/10.1016/j.energy.2015.12.041 


\section{DECLARATION OF CONTRIBUTIONS TO THE ARTICLE - CRediT}

\begin{tabular}{|c|c|c|}
\hline ROLES & Author1 & Author2 \\
\hline $\begin{array}{l}\text { Conceptualization - Ideas; formulation or evolution of overarching research goals and } \\
\text { aims. }\end{array}$ & $\mathrm{X}$ & $\mathrm{X}$ \\
\hline $\begin{array}{l}\text { Data curation - Management activities to annotate (produce metadata), scrub data and } \\
\text { maintain research data (including software code, where it is necessary for interpreting } \\
\text { the data itself) for initial use and later re-use. }\end{array}$ & $\mathrm{X}$ & \\
\hline $\begin{array}{l}\text { Formal analysis - Application of statistical, mathematical, computational, or other } \\
\text { formal techniques to analyze or synthesize study data. }\end{array}$ & $\mathrm{X}$ & \\
\hline $\begin{array}{l}\text { Funding acquisition - Acquisition of the financial support for the project leading to } \\
\text { this publication. }\end{array}$ & - & - \\
\hline $\begin{array}{l}\text { Investigation - Conducting a research and investigation process, specifically } \\
\text { performing the experiments, or data/evidence collection. }\end{array}$ & $\mathrm{X}$ & $\mathrm{X}$ \\
\hline Methodology - Development or design of methodology; creation of models. & $\mathrm{X}$ & $\mathrm{X}$ \\
\hline $\begin{array}{l}\text { Project administration - Management and coordination responsibility for the research } \\
\text { activity planning and execution. }\end{array}$ & $\mathrm{X}$ & \\
\hline $\begin{array}{l}\text { Resources - Provision of study materials, reagents, materials, patients, laboratory } \\
\text { samples, animals, instrumentation, computing resources, or other analysis tools. }\end{array}$ & - & - \\
\hline $\begin{array}{l}\text { Software - Programming, software development; designing computer programs; } \\
\text { implementation of the computer code and supporting algorithms; testing of existing } \\
\text { code components. }\end{array}$ & - & - \\
\hline $\begin{array}{l}\text { Supervision - Oversight and leadership responsibility for the research activity } \\
\text { planning and execution, including mentorship external to the core team. }\end{array}$ & $\mathrm{X}$ & $\mathrm{X}$ \\
\hline $\begin{array}{l}\text { Validation - Verification, whether as a part of the activity or separate, of the overall } \\
\text { replication/reproducibility of results/experiments and other research outputs. }\end{array}$ & $\mathrm{X}$ & $\mathrm{X}$ \\
\hline $\begin{array}{l}\text { Visualization - Preparation, creation and/or presentation of the published work, } \\
\text { specifically visualization/data presentation. }\end{array}$ & $\mathrm{X}$ & \\
\hline $\begin{array}{l}\text { Writing - original draft - Preparation, creation and/or presentation of the published } \\
\text { work, specifically writing the initial draft (including substantive translation). }\end{array}$ & $\mathrm{X}$ & \\
\hline $\begin{array}{l}\text { Writing - review \& editing - Preparation, creation and/or presentation of the } \\
\text { published work by those from the original research group, specifically critical review, } \\
\text { commentary or revision - including pre- or post-publication stages. }\end{array}$ & $\mathrm{X}$ & $X$ \\
\hline
\end{tabular}

